\title{
ANALISIS PRODUKTIVITAS DAN PENDAPATAN TENAGA KERJA PENYADAP KARET DI KABUPATEN JEMBER
}

\author{
Retno Harieswantini ${ }^{1}$, Hariadi Subagja ${ }^{2}$, Muksin $^{2}$ \\ ${ }^{1}$ Mahasiswa Pascasarjana Magister Terapan Politeknik Negeri Jember \\ ${ }^{2}$ Staf Pengajar Politeknik Negeri Jember
}

\begin{abstract}
Rubber plantation development has proven to be the economic driver of the region with a variety of multiplier effect. East Java is one of the potential areas for rubber plantations development. Rubber production in East Java in 2012 amounted to 6,085 tons. This study aims to determine the factors that influence the labor productivity of rubber tappers and differences in productivity, revenue, revenue contributions. This research was conducted by taking locations in Jember by taking Sumberwadung and Durjo plantations as research objects. Data analysis technique used is multiple linear recreation and different test. The analysis show: Labor productivity in plantation rubber tapper Sumberwadung influenced by the outpouring of hours of work, education and training and the environment and work climate. Labor productivity in plantation rubber tapper Durjo influenced by age, environment and climate and the number of family members. Productivity and revenue between growers and Durjo Sumberwadung no different. Labor income between growers and Durjo different Sumberwadung
\end{abstract}

Keywords : Productivity, Income, Income Contribution, Linear Regression.

\section{PENDAHULUAN}

Pembangunan pertanian merupakan salah satu tulang punggung pembangunan nasional dan memiliki peran yang semakinpenting dan strategis. Salah satu sektor pembangunan pertanian yang tidak dapat dipisahkandalam upaya pembangunan pertanian berbasis agribisnis, berbudaya industri dan berorientasi pasar adalah sektor perkebunan (Suwarto, 2010).

Industri perkebunan mulai berkembang di nusantara dalam bentuk usaha-usaha perkebunan berskala besar pada awal abad ke-19. Sejak awal itu hingga menjelang kemerdekaan Indonesia, para pelaku usaha dariBelanda, Inggris, Belgia, dll, mulai membuka perkebunan-perkebunan karet, teh, kopi, tebu, kakao, kina dan beberapa jenis rempah dan lain-lain, lengkap dengan fasilitas pengolahannya terutama di pulau Jawa dan Sumatera (Lembaga Pendidikan Perkebunan, 2011).

Pengembangan perkebunan karet terbukti telah menjadi penggerak perekonomian wilayahdengan berbagai multiplier effect. Jawa Timurmerupakan salah satu wilayah Indonesia yang sangat potensial untuk pengembangan perkebunan karet. Produksi karet Jawa Timur padatahun 2012 sebesar 6.085 ton. Berdasar- kan data Badan Pusat Statistik (BPS) Jawa Timur (2012), luas perkebunan karet terbesar adalah di Kabupaten Jember. Pada Perkebunan Besar Negara komoditas karet kabupaten Jember sebesar 10.215 ha dan Perkebunan besarswastas ebesar 4.268 ha.

Selama periode 2010-2014, sektor pertanian masih merupakan sektor dengan pangsa pasar penyerapan tenaga kerja yang terbesar, walaupun ada kecendrungan menurun. Penyerapan tenaga disektor pertanian pada tahun 2010 sekitar 38,69 juta tenaga kerja atau sekitar $35,67 \%$ dari total penyerapan tenaga kerja. Pada tahun 2014 penyerapan tenaga kerja mengalami penurunan menjadi 35,76 juta tenaga kerja atau $30,27 \%$. Data penyerapan tenaga kerja sektor pertanian tersebut hanya berasal dari kegiatan sektor pertanian primer, belum termasuk sektor sekunder dan tersier dari sistem dan usaha agribisnis. Bila tenaga kerja dihitung dengan yang terserap pada sektor sekunder dan tersiernya, maka kemampuan sektor pertanian tentu akan lebih besar. Walaupun sektor pertanian dalam penyerapan tenaga kerja secara nasional sangat besar, namun di sisi lain justru menjadi beban bagi sektor pertanian dalam meningkatkan produktivitas 
tenaga kerjanya (Kementerian Pertanian, 2015).

Tabel 1. Produktivitas Tenaga Kerja Karet Kab.Jember. Tahun 2008-2013

\begin{tabular}{lll}
\hline No & Tahun & Produktivitas (Rp) \\
\hline 1 & 2008 & 124.866 .000 \\
2 & 2009 & 130.730 .000 \\
3 & 2010 & 141.552 .000 \\
4 & 2011 & 151.655 .000 \\
5 & 2012 & 167.847 .000 \\
6 & 2013 & 157.200 .000 \\
\hline
\end{tabular}

Sumber : Badan Pusat Statistik, 2015.

Tenaga kerja merupakan salah satu elemen esensial bagi kelangsungan hidup perusahaan. Kelancaran proses produksi bergantung pada ketrampilan yang dimiliki oleh tenaga kerja tersebut. Untuk mencapai tujuan maksimum perusahaan, diperlukan pembinaan tenaga kerja dengan suatu sistem yang efektif dan sesuai dengan pola yang terarah (Sastrohadiwiryo, 2005). Tenaga kerja penyadap karet yang bekerja di perkebunan, merupakan tenaga kerja harian lepas yang memiliki upah yang berbeda sesuai dengan produksi yang dihasilkan oleh masing-masing tenaga kerja.

Menurut Setiawan dan Andoko (2008), produktivitas karet yang dikelola rakyat lebih rendah dari pada produktivitas dari pada karet milik Negara atau perusahaan besar karena pengelolanya sangat beda. Pada perkebunan karet milik Negara atau perkebunan besar dikelola secara professional dengan pola sistem nmanajemen yang terstrukur.Produktivitas yang dihasilkan mempengaruhi pendapatan tenaga kerja maupun eksistensi perusahaan yang mengelolanya.

Produktivitas tenaga kerja ditentukan oleh sejauh mana suatu sistem manajemen yang ada dalam perusahaan mampu menunjang kegiatanproduksiperusahaan. Apabila perusahaan peduli dengan keberadaan dan kesejahteraan karyawan, maka karyawan akan berusaha meningkatkan produktivitas kerjanya.Selain itu produktivitas tenaga kerja juga ditentukan oleh karakter dari setiap tenaga kerja yang bersangkutan.Karakteristik tenaga kerja meliputi umur, tingkat pendidikan, tingkat pendapatan, latihan, lama bekerja, jumlah anggota keluarga.

Produktivitas tenaga kerja penyadap karetmemiliki peranan yang sangat pentingse- bagai pihak yang menjalankan kegiatan operasional untuk menghasilkan getah karet yang siap dipasarkan. Peningkatan produktivitas tenaga kerja juga akan berpengaruh terhadap pendapatan tenaga kerja yang memberikan kontribusi terhadap pendapatan rumah tangga, dimana besarnya kontribusi adalah tergantung dari besarnya pendapatan yang diterima oleh tenaga kerja sebagai penyadap karet. Tenaga kerja penyadap karet di Kabupaten Jember akan berusaha meningkatkan produktivitas kerjanya untuk meningkatkan pendapatan sehinga akan meningkatkan kesejahteraan tenaga kerja beserta keluarganya.

Tenaga kerja adalah semua orang yang bekerja untuk perusahaan bisnis, dari tingkatan manager sampai tingkatan supervisor (mandor), tenaga kerja penjualan, tenaga kerja langsung (buruh), dan tenaga kantoran (administrasi).Tenaga kerja sering disebut sebagai sumber daya manusia (SDM) juga mencakup kontribusi orang-orang baik secara fisik maupun mental sewaktu mereka terlibat dalam produksi perekonomian (Jatmiko, 2004). Menurut Simanjuntak (2001), tenaga kerja atau manpower terdiri atas angkatan kerja dan bukan angkatan kerja. Angkatan kerja atau labor force terdiri atas (1) golongan yang bekerja, dan (2) golongan yang menganggur dan mencari pekerjaan. Kelompok bukan angkatan kerja terdiri atas (1) golongan yang bersekolah, (2) golongan yang mengurus rumah tangga, dan (3) golongan lain-lain atau penerima pendapatan.Ketiga golongan dalam kelompok angkatan kerja sewaktu-waktu dapat menawarkan jasanya untuk bekerja.Kesimpulannya kelompok ini juga dinamakan sebagai potential labor force.

Kelancaran proses kerja bergantung pada ketrampilan yang dimiliki tenaga kerja. Tenaga kerja yang memiliki ketrampilan yang tinggi, akan menghasilkan keluaran maksimum sehingga perusahaan akan memperoleh tingkat profitabilitas yang tinggi. Sebaliknya tenaga kerja yang memiliki ketrampilan rendah, keluaran yang dihasilkan pun akan rendah pula sehingga perusahaan akan mendapatkan kerugian. Untuk mencapai tujuan maksimum perusahaan, diperlukan pembinaan tenaga kerja dengan suatu sistem yang efektif dan sesuai dengan pola yang terarah (Sastrohadiwiryo, 2005). 
Kesempatan kerja yang dapat diciptakan oleh suatu perekonomian tergantung pada pertumbuhan dan daya serap masing-masing sektor. Faktor-faktor yang mempengaruhi daya serap tenaga kerja antara lain:

1) Kemungkinan substitusi tenaga kerja dengan faktor produksi yang lain.

2) Elastisitas permintaan terhadap barang yang dihasilkan.

3) Proporsi biaya karyawan terhadap seluruh biaya produksi.

4) Elastisitas persediaan faktor produksi pelengkap lainnya.

Perubahan permintaan tenaga kerja jangka panjang dapat terjadi dalam bentuk loncatan atau shift, dimana perubahan ini diakibatkan oleh adanya perubahan dalam penggunaan teknologi dan metode produksi. Sedangkan untuk meningkatkan daya serap terhadap permintaan tenaga kerja adalah dengan meningkatkan tingkat upah dan pendapatan masyarakat, sehingga akan meningkatkan permintaan konsumsi oleh masyarakat. Perubahan permintaan konsumsi ini akan mempengaruhi permintaan tenaga kerja. Naiknya tingkat pendapatan masyarakat berarti akan meningkatkan permintaan tenaga kerja (Sumarsono, 2003).

Kemajuan teknologi telah mengakibatkan menurunnya presentase penggunaan tenaga kerja manusia di bidang industri dan manufaktur. Kegiatan-kegiatan yang biasanya dikerjakan dengan menggunakan tenaga kerja manusia, sekarang ini telah digantikan oleh mesin-mesin otomatis. Perampingan struktur organisasi bisnis maupun non bisnis merupakan rangkaian dari pesatnya perkembangan teknologi. Sekalipun demikian, peran sumber daya manusia tetap menduduki faktor penting, karena sumber daya inilah yang menjadi perencana dan pengendali semua kegiatan dalam dunia usaha. Tenaga kerja yang bekerja dalam sebuah organisasi atau perusahaan adalah individu-individu yang diharapkan berperan serta dalam mensukseskan tujuan organisasi. Mereka mempunyai tujuan tertentu untuk memuaskan kebutuhannya, dan masing-masing tenaga kerja memiliki kebutuhan yang berbeda-beda dan berubah dari waktu ke waktu selama masa hidup. Begitupun dengan adanya perbedaan generasi, maka akan memunculkan perbedaan kebutuhan (Yuli, 2005).

Struktur umur penduduk dikatakan muda apabila proporsi penduduk umur muda sebanyak $40 \%$ atau lebih sementara kelompok umur tua kurang atau sama dengan 5\%. Sebaliknya suatu struktur umur penduduk dikatakan tua apabila kelompok umur mudanya sebanyak $30 \%$ atau kurang sementara kelompok umur tuanya lebih besar atau sama dengan 10\%. Berdasarkan kategori-kategori tersebut nampak bahwa telah terjadi proses transisi umur penduduk Indonesia dari penduduk muda ke penduduk tua (aging process). Pergeseran struktur umur muda ke umur tua produktif akan membawa konsekuensi peningkatan pelayanan pendidikan terutama pendidikan tinggi dan kesempatan kerja. Sedangkan pergeseran struktur umur produktif keumur tua pada akhirnya akan mempunyai dampak terhadap persoalan penyantunan penduduk usia lanjut. Bersamaan dengan perubahan sosial ekonomi diperkirakan akan terjadi pergeseran pola penyantunan usia lanjut dari keluarga ke institusi. Apabila keadaan ini terjadi, maka tanggung jawab pemerintah akan menjadi bertambah berat (Tjiptoherijanto, 2001).

Secara umum produktivitas diartikan sebagai hubungan antara hasil nyata maupun fisik (barang atau jasa) dengan masuknya yang sebenarnya.Produktivitas juga diartikan sebagai tingkatan efisiensi dalam memproduksi barang-barang atau jasa.L Greenberg mendefinisikan produktivitas sebagai perbandingan antara totalitas pengeluaran pada waktu tertentu dibagi totalitas masukan selama periode tersebut.Ukuran produktivitas berkaitan dengan tenaga kerja yang dapat dihitung dengan membagi pengeluaran oleh jumlah yang digunakan atau jam-jam kerja orang (Sinungan, 2000).

Menurut Sukirno (2005), kenaikan produktivitas disebabkan oleh beberapa factor yang terpenting adalah :

1. Kemajuan teknologi

Kemajuan teknologi memungkinkan pergantian kegiatan ekonomi dari penggunaan binatang dan manusia kepada tenaga mesin, penggantian ini dapat meningkatkan produktivitas.Kemajuan teknologi juga dimanfaatkan untuk memperbaiki mutu dan kemampuan mesin-mesin yang digunakan. Selainitu tujuan yang paling penting adalah memperbaiki efisiensi produksi, dan ini akan meninggikan produktivitas kegiatan memproduksi. 


\section{Pertambahan kepandaian dan keterampilan} kerja

Kemajuan ekonomi mempertinggi taraf kesehatan masyarakat, taraf pendidikan dan latihan teknik dan menambah pengalaman dalam pekerjaan.

3. Perbaikan dalam organisasiperusahaan dan masyarakat

Dalam perekonomian yang mengalami kemajuan bentuk manajemen perusahaan mengalami perubahan.Dengan perubahan ini organisasi perusahaan diperbaiki dan diselenggaran menurut cara-cara manajemen modern.

Produktivitas sering dihubungkan dengan output, kinerja, efisiensi dan efektivitas. Secara umum pengertian produktivitas merupakan rasio output terhadap input. Dimana input meliputi biaya produksi (production cost) dan biaya peralatan (equipment cost). Output terdiri dari penjualan (sales), pendapatan (earning), dan kerusakan pada kegiatannya. Bahkan ada yang memberikan penekanan produktivitas pada nilai efisiensi. Pengukuran efisiensi menghendaki penentuan output dan penentuan jumlah sumberdaya yang dipakai untuk menghasilkan output tersebut (Gomes, 2002).

Menurut Sinungan (2000), produksi berkaitan dengan jumlah hasil yang dicapai, sedangkan produktivitas berkaitan dengan cara pencapaian tingkat produksi tersebut. Dalam pengukuran produktivitas dikenal dengan dua cara pendekatan:

1. Pendekatan produktivitas total atau faktor ganda yaitu output dihadapkan dengan seluruh input yang dipakai.

2. Pendekatan partial atau faktor tunggal yaitu output dihadapkan dengan satu input saja (seperti produktivitas tenaga kerja atau produktivitas modal).

Lebih lanjut dikatakan oleh Sinungan (2000), pengukuran produktivitas tenaga kerja menurut sistem pemasukan fisik perorangan ataupun setiap jam kerja orang diterima secara luas. Dari sudut pengawasan harian pengukuran tersebut pada umumnya bervariasi dalam jumlah yang diperlukan untuk memproduksi satu unit produk yang berbeda. Oleh karena itu digunakan metode pengukuran waktu tenaga kerja yang biasanya diartikan sebagai jumlah kerja dalam setiap jam oleh pekerja yang terpercaya dalam bekerja menurut pelaksanaan yang standar. Dengan demikian dapat disimpulkan bahwa produktivitas kerja merupakan kemampuan bekerja seseorang dalam satuan waktu.

Menurut Soekemi (1988), produktivitas tenaga kerja dipengaruhi oleh berbagai faktor baik yang berhubungan dengan tenaga kerja itu sendiri maupun faktor-faktor lainnya, antara lain seperti :

a. Pendidikan dan pelatihan

Faktor pendidikan dan pelatihan secara langsung akan menambah kemampun kerja atas peningkatan pengetahuan maupun ketrampilan. Dengan demikian, pendidikan dan pelatihan akan meningkatkan produktivitas kerja yang secara ekonomis akan menghasilkan nilai tambah spesifik ataupun mutlak yang semakin membesar. Kenyataan membuktikan bahwa negara-negara ekonomi kuat dengan tingkat pendidikan yang lebih tinggi bagi rata-rata penduduknya. Berdasarkan pernyataan Dewan Produktivitas Nasional, besarnya upah atau gaji sebagai pencerminan dari produktivitas kerja memberikan bukti bahwa pendapatan rata-rata pekerja dengan pendidikan yang lebih tinggi pasti lebih besar dibandingkan pekerja lainnya. Selain itu, dengan adanya pelatihan bagi tenaga kerja dimaksudkan untuk lebih memantapkan ketrampilannya pada pekerjaannya serta dapat mengikuti perkembangan teknologi.

b. Sikap dan disiplin

Peningkatan produktivitas kerja tidak hanya dipengaruhi oleh tingkat pendidikan, ketrampilan, dan lain-lain, akan tetapi dipengaruhi juga oleh sikap dan disiplin kerja. Ketrampilan yang tinggi sekalipun, tidak akan menghasilkan produk yang maksimal apabila yang bersangkutan tidak memanfaatkan ketrampilannya secara teratur dan disiplin. Demikian pula penerapan teknologi maju tidak memberikan hasil maksimal apabila tenaga kerja tidak mempunyai kesungguhan sikap dan disiplin kerja. Tenaga kerja yang tidak bersungguh-sungguh dan tidak disiplin akan membuat perusahaan tidak berkembang dengan baik sehingga kemampuan perusahaan akan menjadi terbatas untuk memperbaiki kesejahteraan tenaga kerja. Sikap dan disiplin kerja pada perusahaan tidak tumbuh dengan sendirinya dan tidak dapat dijamin dengan memberikan upah yang tinggi saja, akan tetapi sikap dan disiplin kerja perlu ditumbuhkan dan dikembangkan baik melalui pembinaan hubungan industrial yang serasi maupun secara terprogram melalui 
motivator-motivator yang timbul dari golongan tenaga kerja sendiri.

c. Motivasi

Motivasi merupakan suatu daya pendorong atau perangsang untuk melakukan sesuatu dalam rangka mencapai tujuan tertentu atau melatarbelakangi seseorang untuk berbuat sesuatu dalam mencapai tujuan tertentu. Tenaga kerja yang memiliki tingkat motivasi kerja yang tinggi akan berpengaruh pada produktivitas. Motivasi timbul karena adanya penyebab subjektif yang berasal dari dalam diri orang yang bersangkutan seperti kebutuhan makan dan penghargaan, maupun aspek objektif yang berasal dari luar orang yang bersangkutan seperti adanya penerimaan insentif dari perusahaan.

\section{d. Gizi dan kesehatan}

Keadaan gizi dan kesehatan yang baik memberikan kemampuan serta kesegaran fisik dan mental seseorang dalam melakukan pekerjaan. Semakin baik keadaan gizi dan kesehatan seseorang, maka semakin tinggi tingkat produktivitasnya. Kekurangan gizi masyarakat bukan saja menghambat pertumbuhan anakanak dan mengganggu kesehatan rumah tangga, tetapi juga secara langsung mempengaruhi produktivitas tenaga kerja. Keadaan gizi dan kesehatan seseorang juga mempengaruhi kemampuannya dalam pendidikan dan pelatihan. Oleh sebab itu, keadaan gizi dan kesehatan yang rendah dalam masyarakat secara tidak langsung menimbulkan produktivitas kerja yang rendah karena tingkat pendidikan dan ketrampilan umumnya juga rendah.

e. Tingkat penghasilan dan jaminan sosial

Faktor penghasilan dan jaminan sosial dalam arti imbalan atau penghargaan dapat menjadi pendorong atau insentif agar tenaga kerja bekerja giat atau lebih produktif. Pada perusahaan-perusahaan, pemberian penghasilan dan jaminan sosial bukan hanya untuk menjamin pemberian atas prestasi seseorang, tetapi juga untuk mendorong setiap kemajuan agar tenaga kerja berprestasi lebih baik.

f. Lingkungan dan iklim kerja

Salah satu faktor penting yang juga mempengaruhi manusia dalam mencapai produktivitas kerjanya adalah dengan memperhatikan lingkungan kerjanya. Lingkungan kerja adalah segala sesuatu di lingkungan pekerjaan yang memudahkan atau menyulitkan pekerjaan termasuk faktor penerangan, suhu udara, venti- lasi, kursi dan meja. Apabila lingkungan kerja buruk maka hasil kerjanya juga buruk akibat dari pemborosan, tidak ekonomis ataupun kerugian.

g. Kesempatan berprestasi

Tingkat produktivitas tenaga kerja juga sangat tergantung pada kesempatan kerja yang terbuka padanya. Kesempatan dalam hal ini berarti (a) kesempatan untuk bekerja, (b) pekerjaan yang sesuai dengan pendidikan dan ketrampilan tiap-tiap orang dan (c) kesempatan mengembangkan diri. Rendahnya produktivitas kerja seseorang sering diakibatkan oleh salah penempatan kerja, dalam arti bahwa seseorang itu tidak ditempatkan dalam pekerjaan yang sesuai dengan pendidikan dan ketrampilannya. Oleh karena itu, perusahaan akan memperoleh hasil yang lebih besar apabila tiap tenaga kerja ditempatkan sesuai dengan pendidikan dan ketrampilan yang dimiliki (Soekemi, 1988)

Produktivitas digunakan untuk mengukur bagaimana baiknya suatu sumber daya diatur dan dimanfaatkan untuk mencapai hasil yang diinginkan.Secara umum, produktivitas dapat dinyatakan sebagai rasio antara keluaran terhadap masukan, atau rasio hasil yang diperoleh terhadap sumberdaya yang digunakan (Herjanto, 1999).Berikut cara yang digunakan dalam perhitungan produktivitas, sebagai berikut :

Produktivitas $=\frac{\text { keluaran }}{\text { masukan }}=\frac{\text { hasil yang diperoleh }}{\text { sumber daya yang digunakan }}$

Apabila dalam rasio tersebut masukan yang digunakan untuk menghasilkan keluaran dihitung seluruhnya maka disebut dengan produktivitas total (total factor productivity). Akan tetapi apabila yang dihitung sebagai masukan hanya komponen tertentu saja misalnya tenaga kerja, maka disebut produktivitas parsial (partial productivity). Berikut ini cara perhitungan untuk produktivitas tenaga kerja (Herjanto, 1999) :

Produktivitas $=\frac{\text { keluaran }}{\text { masukan }}=\frac{\text { hasil yang diperoleh }}{\text { jam kerja per orang }}$

Produktivitas pekerja dapat dinyatakan secara mudah sebagai perbandingan antara jumlah yang dihasilkan dan jumlah tiap sumber yang dipakai selama produksi berlangsung. Da- 
lam hubungan ini perlu diperhatikan dari segi waktu karena output produksi yang memuaskan dari seorang pekerja dalam waktu tertentu itulah yang digunakan sebagai dasar perhitungan. Oleh karena itu, produktivitas diukur dari keluaran (output) barang ataupun jasa dalam satuan waktu per orang. Besarnya produktivitas tenaga kerja akan mempengaruhi tingkat pendapatan tenaga kerja penyadap karet.

\section{Teori Pendapatan dan Sistem Pengupahan}

Sebagai penyadap karet merupakan sumber utama pendapatan masyarakat sekitar perkebunan (Munawaroh dkk., 2013). Di perkebunan tersebut, usaha perkebunan rakyat menjadi sumber utama pendapatan penduduk sekitar perkebunan. Pendapatan merupakan suatu penghasilan yang diperoleh seorang atau masyarakat dalam waktu tertentu, di mana hasil tersebut dapat bersumber dari produksi, jasa atau harta kekayaan lainnya sedangkan gambaran tentang pendapatan adalah posisi ekonomi keluarga tersebut dalam masyarakat. Pendapatan diperoleh sebagai hasil kerja atau jasa aset dan sumbangan dari pihak lain dari berbagai sumber pendapatan yang ada, maka dapat digolongkan sebagai sumber pendapatan utama dan sumber pendapatan tambahan berdasarkan besarnya pendapatan. Kumpulan pendapatan dari berbagai sumber tersebut merupakan total pendapatan.

Pengertian upah menurut Pasal 1 ayat 30 PP No. 13/2003, suatu penerimaan sebagai imbalan dari pengusaha kepada karyawan untuk suatu pekerjaan atau jasa yang telah atau akan dilakukan dan dinyatakan atau dinilai dalam bentuk uang ditetapkan atas dasar persetujuan atau peraturan perundang-undangan serta dibayarkan atas dasar suatu perjanjian kerja antara pengusaha dengan karyawan itu sendiri maupun untuk keluarganya. Upah pada dasarnya merupakan sumber utama penghasilan seseorang, sebab itu, upah harus cukup untuk memenuhi kebutuhan karyawan dan keluarganya dengan wajar.Kewajaran dapat dinilai dan diukur dengan kebutuhan hidup minimum atau sering disebut Kebutuhan Fisik Minimum (KFM) (Sumarsono, 2003).

Masalah utama yang dapat timbul dalam bidang pengupahan adalah bahwa pengusaha dan karyawan pada umumnya mempunyai pengertian dan kepentingan yang berbeda mengenai upah. Bagi pengusaha, upah dapat dipandang sebagai beban, karena semakin besar proporsi upah yang dibayarkan kepada karyawan, semakin kcil keuntungan bagi pengusaha. Segala sesuatu yang dikeluarkan oleh pengusaha sehubungan dengan mempekerjakan seseorang dipandang sebagai komponen upah : uang tunai (gaji), tunjangan beras, pengangkutan, kesehatan, konsumsi yang disediakan dalam menjalankan tugas, pembayaran upah waktu libur, cuti dan sakit, fasilitas rekreasi dan lain-lain. Di pihak lain karyawan dan keluarganya biasanya menganggap upah hanya sebagai apa yang diterimanya dalam bentuk uang (Sumarsono, 2003).

Kenyataan menunjukkan bahwa hanya sedikit pengusaha yang secara sadar dan sukarela terus menerus berusaha meningkatkan penghidupan karyawannya, terutama pekerja golongan paling rendah. Di pihak lain, karyawan melalui Serikat Pekerja dan/atau dengan mengundang campur tangan Pemerintah selalu menuntut kenaikan upah. Tuntutan seperti itu yang tidak disertai dengan peningkatan produktivitas kerja akan mendorong pengusaha : (1) mengurangi penggunaan tenaga kerja dengan menurunkan produksi; (2) menggunakan teknologi yang lebih padat modal; dan/atau (3) menaikkan harga jual barang yangkemudian mendorong inflasi (Sumarsono, 2003).

Hasil kajian yang dilakukan oleh Haryanto (2008) menyimpulkan bahwa terdapat kontribusi yang signifikan kontibusi pendapatan pekerja terhadap pendapatan rumah tangga. kontribusipendapatan adalah suatu hasil yang diperoleh seseorang atau masyarakat dalam waktu tertentu, dimana hasil tersebut dapat bersumber dari produksi, jasa atau harta kekayaan lainnya Lestari et al. (1997). Sedangkan pendapatan rumah tangga adalah aliran uang.Barang, jasa serta kepuasan yang diperoleh di bawah penguasaan keluarga untuk digunakan dalam memuaskan dan memenuhi kebutuhannya.Pendapatan rumah tangga berasal lebih dari satu sumber pendapatan. Sumber pendapatan yang beragam tersebut dapat terjadi karena anggota rumah tangga yang bekerja, melakukan lebih dari satu jenis pekerjaan dan atau masing-masing anggota keluarga mempunyai kegiatan yang berbeda satu sama lainnya.

Menurut Kamus Besar Bahasa Indonesia, kontribusi berasal dari Bahasa Inggris contribution yang artinya adalah sumbangan atau 
sokongan. Nilai kontribusi atau sumbangan suatu komoditas terhadap pendapatan rumah tangga dapat diketahui dengan menggunakan teknik analisis proporsi atau analisis kontribusi. Kontribusi pendapatan dilakukan dengan membandingkan pendapatan usahatani terhadap total pendapatan rumah tangga petani. Nilai kontribusi tidak memiliki satuan, tetapi berupa presentase (Sundari, dkk, 2012).

Menurut Lestari et al. (1997) kontribusi merupakan segala sesuatu yang diterima oleh seseorang setelah melakukan berbagai usaha yang dapat memberikan dampak masukan baik itu berupa uang maupun sumberdaya. Besarnya kontribusi pendapatan yang diberikan tenaga kerja penyadap karet terhadap pendapatan keluarga dapat diketahui dengan uji proporsi yaitu dengan membandingkan total pendapatan tenaga kerja penyadap karet dengan total pendapatan keluarga yang diformulasikan sebagai berikut :

Keterangan :

$$
\mathrm{Z}=\mathrm{A} / \mathrm{B} \times \mathbf{1 0 0} \%
$$

$\mathrm{Z}=$ Kontribusi Tenaga Kerja

$\mathrm{A}=$ Pendapatan Tenaga Kerja

$\mathrm{B}=$ Pendapatan Rumah Tangga

Kontribusi pendapatan tenaga kerja penyadap karet dikategorikan sebagai berikut:

1) $Z<35 \%$, maka kontribusi pendapatan tenaga kerja penyadap karet terhadap pendapatan rumah tangga adalah rendah.

2) $35 \% \leq Z \leq 70 \%$, maka kontribusi pendapatan tenaga kerja penyadap karet terhadap pendapatan rumah tangga adalah sedang.

3) $Z>70 \%$, maka kontribusi pendapatan tenaga kerja penyadap karet terhadap pendapatan rumah tangga adalah tinggi

\section{METODE PENELITIAN}

Penentuan populasi dengan menggunakan purposive sample yaitu perkebunan Sumberwadung sebagai perwakilan perkebunan pemerintah dan perkebunan Durjo sebagai perwakilan perkebunan swasta. Penentuan jumlah sampel dengan menggunakan rumus slovin untuk dua perkebunan tersebut. Diperoleh jumlah sampel 39 responden untuk perkebunan Sumberwadung dan 35 responden untuk perkebunan Durjo. Analisis data yang digunakan yaitu : 1) Analisis regresi berganda untuk mengetahui faktor-faktor yang berpengaruh terhadap produktivitas tenaga kerja penyadap karet. 2) Uji beda untuk mengetahui perbedaan produktivitas, pendapatan dan distribusi pendapatan.

\section{HASIL DAN PEMBABASAN Produktivitas Tenaga Kerja Penyadap Karet}

Produktivitas tenaga kerja penyadap karet pada Perkebunan Sumberwadung dan perkebunan Durjo menggambarkan kemampuan tenaga kerja untuk menyelesaikan pekerjaanya dalam satuan waktu. Faktor-faktor yang diduga mempengaruhi produktivitas kerja tenaga kerja penyadap karet di Perkebunan Sumber wadung adalah curahan jam kerja (X1), pendidikan dan pelatihan kerja (X2), umur (X3), pengalaman (X4), lingkungan dan iklim kerja (X5), jumlah anggota keluarga (X6) dankeselamatan dan kesehatan kerja (X7). Besarnya pengaruh ketujuh faktor-faktor di atas terhadap tingkat produktivitas tenaga kerja penyadap karet dapat diketahui dengan melakukan analisis regresi linear berganda.Di mana produktivitas merupakan variabel terikat $(\mathrm{Y})$, sedangkan ketujuh faktor di atas merupakan variabel bebas yang diduga mempengaruhi $\mathrm{Y}$.

Tabel 2 merupakan pengaruh dari masing-masing variabel bebas $(\mathrm{X})$ terhadap variabel terikat (Y). Berdasarkan tabel tersebut maka, variabel X1 sampai dengan $X 7$ variabel bebas yang diteliti oleh peneliti yang mempengaruhi produktivitas tenaga kerja penyadap karet di Perkebunan Sumberwadung adalah Curahan jam kerja (X1), Pendidikan dan pelatihan (X2), dan Lingkungan dan iklim kerja (X5). Dengan demikian maka H0 untuk curahan jam kerja, Pendidikan dan pelatihan serta Lingkungan dan iklim ditolak. Sekaligus menerima H1 untuk curahan jam kerja, Pendidikan dan pelatihan serta Lingkungan dan iklim diterima. Maka dapat disimpulkan bahwa : X1 (Curahan jam kerja) berpengaruh secara signifikan terhadap produktivitas tenaga kerja penyadap karet di Perkebunan Sumberwadung Jember. X3 (Pendidikan dan pelatihan) berpengaruh secara signifikan terhadap produktivitas tenaga kerja penyadap karet perkebunan Sumberwadung Jember. Dan X5 (Lingkungan dan Iklim kerja) berpengaruh secara signifikan terhadap produktivitas tenaga kerja penyadap karet perkebunan Sumberwadung Jember. Sementara untuk X2, X4, X6, X7 dinyatakan berpengaruh tidak signifikan. 
Tabel 2. Hasil analisis regresi linier berganda

\begin{tabular}{lllll}
\hline \multirow{2}{*}{ Variabel } & \multicolumn{3}{l}{ Sumberwadung } & Durjo \\
\cline { 2 - 5 } & $\mathrm{t}$ & Sig. & $\mathrm{t}$ & $\mathrm{Sig}$. \\
\hline Curahan jam kerja & 2,242 & 0,032 & $-0,624$ & 0,538 \\
Pend dan Pelatihan & 2,999 & 0,005 & $-0,096$ & 0,924 \\
Umur & $-0,172$ & 0,865 & 2,792 & 0,009 \\
Pengalaman & 0,976 & 0,337 & $-0,162$ & 0,873 \\
Lingkungan \& Iklim & 2,403 & 0,022 & 3,546 & 0,001 \\
Jumlah anggota keluarga & 1,086 & 0,286 & 2,256 & 0,032 \\
K3 & 0,060 & 0,952 & $-0,439$ & 0,664 \\
\hline
\end{tabular}

Sumber : Data Primer diolah, 2015

Dari Tabel 2 dari Variabel X1 sampai dengan X7 variabel bebas yang diteliti oleh peneliti yang mempengaruhi produktivitas tenaga kerja penyadap karet di Perkebunan Durjo yaitu X3 (umur), X5 (Lingkungan dan iklim), dan X6 (Jumlah anggota keluarga). Dengan demikian maka H0 untuk umur, Lingkungan dan iklim sertajumlah anggota keluarga ditolak. Sekaligus menerima H1 untuk umur, Lingkungan dan iklim dan jumlah anggota keluarga. Maka dapat disimpulkan bahwa X3 (umur) berpengaruh secara signifikan terhadap produktivitas tenaga kerja penyadap karet di Perkebunan Durjo Jember. X5 (lingkungan dan iklim) berpengaruh secara signifikan terhadap produktivitas tenaga kerja penyadap karet perkebunan Durjo Jember. Dan X6 (Jumlah anggota keluarga) berpengaruh secara signifikan terhadap produktivitas tenaga kerja penyadap karet perkebunan Durjo Jember. Sementara untuk X1, X2, X4, X7 dinyatakan berpengaruh tidak signifikan.

Hasil model summary pada penelitian ini didapat hasil yang dijelaskan pada Tabel 3 dibawah ini :

Tabel 3. Model Summary

\begin{tabular}{lccl}
\hline \multicolumn{1}{c}{ Model } & $\mathrm{R}$ & $\begin{array}{c}\mathrm{R} \\
\text { Square }\end{array}$ & $\begin{array}{c}\text { Sig. F } \\
\text { Change }\end{array}$ \\
\hline Sumberwadung & $0,827^{\mathrm{a}}$ & 0,684 & 0,000 \\
Durjo & $0,834^{\mathrm{a}}$ & 0,696 & 0,000 \\
\hline
\end{tabular}

Sumber : Data Primer diolah, 2015

Dari Tabel 3 didapat hasil dari model summary nilai $\mathrm{R}$ Square sebesar 0,684 untuk perkebunan Suerwadung.Dengan demikian maka variabel produktivitas tenaga kerja perkebunan Sumberwadung mampu dijelaskan oleh curahan jam kerja, pendidikan dan pelatihan, umur, pengalaman kerja, jumlah anggota keluarga, lingkungan dan iklim kerja dan keselamatan dan kesehatan kerja sebesar $68,4 \%$ sisanya
$31,6 \%$ dipengaruhi oleh variabel lain yang tidak dimasukkan dalam model.Dari Tabel 3 diperoleh hasil dari model summary nilai R Square sebesar 0,696 untuk perkebunan Durjo. Dengan demikian maka, variabel produktivitas mampu dijelaskan oleh curahan jam kerja, umur, pendidikan dan pelatihan kerja, pengalaman kerja, jumlah anggota keluarga, keselamatan dan kesehatan kerja dan lingkungan dan iklim kerja sebesar $69,6 \%$ sisanya $30,4 \%$ dipengaruhi oleh variabel lain yang tidak dimasukkan dalam model.

Temuan untuk perkebunan Sumberwadung secara empirik menunjukkan bahwa tinggi rendahnya produktivitas tenaga kerja penyadap karet di Perkebunan Sumberwadung sangat dipengaruhi oleh curahan jam kerja, sesuai dengan apa yang disampaikan oleh Bunasor (1978) dalam Waluyo (1993), pendidikan dan pelatihan ini sesuai dengan kajian yang dilakukan oleh Soekemi (1988) dan lingkungan dan ikliam sesuai dengan kajian yang dilakukan oleh Soekemi (1988).

Temuan untuk perkebunan Durjo secara empirik menunjukkan bahwa tinggi rendahnya produktivitas tenaga kerja penyadap karet di Perkebunan Durjo akan dipengaruhi oleh umur, sesuai dengan apa yang disampaikan oleh Tjiptoherijanto (2001), lingkungan dan ikliam sesuai dengan kajian yang dilakukan oleh Soekemi (1988) dan jumlah anggota keluarga sesuai dengan kajian yang dilakukan oleh Lestari et al. (1997).

\section{Perbedaan Produktivitas, Pendapatan, Kon- tribusi.}

Hasil perbandingan uji T.Test Produktivitas, Pendapatan dan kontribusi dari tenaga kerja penyadap karet pada dua perusahaan dapat dilihat pada Tabel 4 di bawah ini : 
Tabel 4. Test Independent Sampel Test.

\begin{tabular}{|c|c|c|c|c|}
\hline & $\mathbf{T}$ & df & Sig. 2 (2-tailed) & Ket. \\
\hline Produktivitas & $-0,753$ & 71 & 0,454 & Tidak berbeda \\
\hline Pendapatan & 2,164 & 71 & 0,034 & Berbeda \\
\hline Kontribusi & 0,059 & 71 & 0,953 & Tidak berbeda \\
\hline
\end{tabular}

Sumber : Data Primer diolah, 2015.

Dari Tabel 4 didapat hasil : produktivitas dari dua perkebunan tidak berbeda nyata. Hasil produktivitas Perkebunan Sumberwadung dengan Perkebunan Durjo dengan tingkat signifikan 0,05 atau $5 \%$ tidak berbeda nyata karena $\operatorname{sig}=0,454$ lebih besar dari 0,05.Temuan ini menunjukkan bahwa tidak ada perbedaan produktivitas tenaga kerja penyadap karet antara perkebunan Sumberwadung dengan perkebunan Durjo Jember. Pendapatan tenaga kerja dari kedua perkebunan ini berbeda nyata karena sig $=0,034$ lebih kecil dari signifikan 0,05 atau $5 \%$.Temuan ini menunjukkan bahwa terdapat perbedaan pendapatan tenaga kerja penyadap karet antara perkebunan Sumberwadung dengan perkebunan Durjo Jember. Kontribusi pendapatan tenaga kerja terhadap pendapatan keluarga, pada kedua perusahaan tidak berbeda nyata, karena sig $=0,953$ lebih besar signifikan 0,05 atau 5\%.Temuan ini menunjukkan bahwa tidak ada perbedaan kontribusi tenaga kerja penyadap karet antara Perkebunan Sumberwadung dengan Perkebunan Durjo Jember.

\section{KESIMPULAN}

1. Produktivitas tenaga kerja penyadap karet pada Perkebunan Sumberwadung dipengaruhi oleh Curahan jam kerja, Pendidikan dan pelatihan dan Lingkungan dan Iklim kerja.

2. Produktivitas tenaga kerja penyadap karet pada Perkebunan Durjodipengaruhi oleh: umur, lingkungan dan iklim dan Jumlah anggota keluarga.

3. Produktivitas dan kontribusi pendapatan antara perkebunan Sumberwadung dan Durjo tidak berbeda.Pendapatan tenaga kerja antara perkebunan Sumberwadung dan Durjo berbeda.

\section{DAFTAR PUSTAKA}

BPS Jatim, 2015. Badan Pusat Statistik Jawa Timur. http://www.jatim.bps.go.id/

Kementrian Pertanian Republik Indonesia, 2015. Rencana Strategis Kementrian Pertanian 2015-2019. www.pertanian.go.id

Lembaga Pendidikan Perkebunan, 2011. Profile Pusat Informasi BUMN Perkebunan. http://pp.ac.id

Gomes F. C., 2002. Manajemen Sumber Daya Manusia. Yogyakarta: Penerbit Andi

Haryanto, Sugeng. 2008. Peran Aktif Wanita Dalam Peningkatan Pendapatan RumahTangga Miskin: Studi Kasus Pada Wanita Pemecah Batu DiPucanganak Kecamatan Tugu Trenggalek. Jurnal Ekonomi Pembangunan, 9(2): 216 - 227.

Herjanto, Eddy. 1999. Manajemen Produksi dan Operasi EdisiKedua. Jakarta: Grasindo.

Lestari, Rahayu Endah. Santoso, Imam. Sulastri, Dwi Rina. 1997. KontribusiWanita dalam Agribisnis Gula semut diKabupaten Blitar Propinsi Jawa Timur.Jurnal Penelitian Ilmu-Ilmu Sosial,9(1).

Munawaroh,Malihatin., Sri Wahyuningsih dan Shofia Nur Awami. 2013. Kontribusi Buruh Wanita Penyadap KaretTerhadap Pendapatan Keluarga(Studi Kasus di PTPN IX Kebun Balong/Beji-KaliteloAfdelling Ngandong Kabupaten Jepara). MEDIAGRO362(2): 36-45.

Sastrohadiwiryo, Siswanto. 2005. Manajemen Tenaga Kerja Indonesia, Pendekatan Administratif dan Operasional. Jakarta: PT. 
Bumi Aksara.

Setiawan, H.D dan Andoko, A. 2008.Karet.Jakarta : Agromedia Pustaka.

Simanjuntak. 2001. Pengantar Ekonomi Sumber Daya Manusia. Jakarta: Univesitas Indonesia

Sinungan. 2000. Produktivitas Apa dan Bagaimana. Jakarta : Bumi Aksara.

Soekemi, Sri L., 1988. Hubungan Ketenagakerjaan. Jakarta: Karunika.

Sukirno, Sadono. 2005. Mikro Ekonomi Teori Pengantar edisi ketiga.PT.Rajagrafindo Persada : Jakarta.

Sumarsono, Sony. 2003.Ekonomi Manajemen Sumber Daya Manusia dan Ketenagakerjaan. Graha Ilmu: Yogjakarta.

Sundari,Hany Andewi., Zulfanita dan Dyah Panuntun Utami. 2012. Kontribusi Usahatani Ubi Jalar (Ipomoea batatas L.)Terhadap Pendapatan Rumah Tangga PetaniDi Desa Ukirsari Kecamatan GrabagKabupaten Purworejo. SURYA AGRITAMA1(2) : $34-45$.

Suwarto, 2010.Budidaya 12 Tanaman Perkebunan Unggulan.Penebar Swadaya. Jakarta.

Tjiptoherijanto, Prijono. 2001. Proyeksi Penduduk, Angkatan Kerja, TenagaKerja, dan Peran Serikat Pekerja dalam Peningkatan Kesejahteraan.Majalah Perencanaan Pembangunan. Edisi 23.

Waluyo. 1993. Kajian Kelangkaan Tenaga Kerja Pemetik Kopi. Fakultas Pertanian Universitas Jember. Universitas Jember.

Yuli, Sri Budi Cantika. 2005.Manajemen Sumber Daya Manusia. Cetakan Pertama. UMM Press: Malang. 